BIOKEMISTRI 17(2):73-81 (Dec 2005)

Available online at http://www.bioline.org.br/bk.

Abstracted online at www.ajol.info/journals/biokem

Printed in Nigeria
An international journal published by the

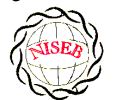

OVigerian Bociety for \&̊xperimental \&iology

\title{
Effect of some chemicals on the accuracy of protein estimation by the Lowry method
}

\section{Sébastien NIAMKE ${ }^{1,3^{*}}$, Lucien Patrice KOUAME ${ }^{2}$, Jean Parfait KOUADIO ${ }^{2}$, Didier KOFFI $^{2}$, Betty Meuwiah FAULET ${ }^{2}$ and Soumaila DABONNE}

\section{Laboratoire de Biotechnologies, Unité de Formation et de Recherche en Biosciences de} l'Université de Cocody-Abidjan, 22 BP 582 Abidjan 22, Côte d'Ivoire.

2. Laboratoire de Biochimie et Technologie des Aliments, Unité de Formation et de Recherche en Sciences et Technologie des Aliments de l'Université d'Abobo-Adjamé, 02 BP 801 Abidjan 02, Côte d'Ivoire.

3. Laboratoire de Biochimie, Unité de Biotechnologie, Biocatalyse et Biorégulation CNRS-UMR 6204. Faculté des Sciences et des Techniques, 2 rue de la Houssinière, BP 92208, F 44322, Nantes cedex 3, France.

Received 20 May 2005

MS/No BKM/2005/026, ( 2005 Nigerian Society for Experimental Biology. All rights reserved.

\begin{abstract}
The influence of 57 chemicals (mineral and organic acids, organic solvents, phenolic compounds, mineral and organic salts) on the efficiency of protein determination by the Lowry method was assessed. The study revealed the Lowry method to be unreliable in an acidic and increasing vitamin C-rich medium. For organic solvents, it is advisable to evaporate these compounds when they are used to extract proteins, prior to proteins measurement the Lowry method. The influence of phenolic compounds on the Lowry method was found to be governed by the structure of their molecules (presence of double bounds, number of $\mathrm{OH}$ groups, presence of methyl groups, etc.), while ammonium sulfate, which is a major agent used in the enzyme purification process, was found to result in an overestimation of the protein content. Therefore, its use for enzyme purification should be done with caution.
\end{abstract}

Key words: Lowry method, protein determination, method validation, chemical interference

*Author to whom all correspondence should be addressed.

E-mail: niamkes@yahoo.fr; Fax: (225) 20378118 ; Tel: (225) 07846409 


\section{INTRODUCTION}

Several methods are used to measure the protein content of different food products, enzymatic solutions and other biological mixtures. These methods include that of Kjeldahl $^{1}$, which allows the extrapolation of protein content from the estimation of the amount of nitrogen. In this method, the food product is mineralized with a boiling sulfuric acid solution and the amount of ammonium ions formed is determined. The method of Biuret ${ }^{2}$ allows the determination of protein content from the quantification of peptide bonds with the aid of $\mathrm{Cu}^{2+}$ ion in an alkaline environment containing chelating molecules such as tartrate or EDTA. The method of Smith et al. ${ }^{3}$ allows the protein content determination through their peptide bonds. Indeed, the bicinchoninic acid gives shape to a stable complex with copper ions in an alkaline environment with a peptide bond. This method is very similar to that of Biuret ${ }^{2}$. The method of Bradford ${ }^{4}$ uses the Coomassie blue G 200 which reacts with proteins particulary on the cationic groups and aromatic rings. The absorption in the ultra-violet regions reveals the peptide bond which absorbs at around $214 \mathrm{~nm}$ and the aromatic groups (phenylalanine, tyrosine and moreover tryptophane), which give a large band at 280 $\mathrm{nm}$. The method of Lowry et al. ${ }^{5}$ combines the reaction of Biuret ${ }^{2}$ with the action of a mercury reagent of phenols, the reagent of FolinCiocalteus. It quantifies both of the peptide bonds and the tyrosine residues.

Among the methods quoted, that of Lowry seems to be the most used to determine the amounts of protein contained in biological or chromatographic solutions. However, these environments are often heterogeneous as they contain other molecules which can interact with the proteins to be measured or with the reagent used. This could lead to errors in the estimation of the protein content of these solutions. Therefore, in this work, we examined the effect of a variety of chemicals (mineral and organic acids, organic solvents, phenolic compounds, mineral and organic salts) on the accuracy of protein measurement by the Lowry method.

\section{MATERIALS AND METHODS}

\section{Chemicals}

Barium chloride, trichloroacetic acid, phenol, $o$-boric acid, ammonium sulfate, sodium acetate, potassium di-hydrogen phosphate, sodium hydrogen carbonate, $p$-nitrophenol, ammonium monovanate, copper sulfate (II), ammonium sulfate (III) and bisublimed iodide were obtained from Merck (Darmstadt, Germany);

$o$-Saccharic acid, naphto-resorcinol, molybdic acid, orcinol, propanol-1 and methyl2-propanol-1, potassium sulfate, 2-naphtol, copper acetate (II), propionic acid, metaphosphoric acid, sodium thiosulfate, sodium sulfate, isobutanol and sodium hypochloride, calcium chloride, calcium hypochloride, ammonium molybdate, hydrochloric acid, calcium carbonate, sodium dihydrogen phosphate, oxalic acid, potassium hexacyanoferrate (II), ammonium oxalate, sodium oxalate and resorcinol were purchased from Sigma-Aldrich (Lyon, France);

Sulfuric acid, methanol, acetic acid, Lascorbic acid, L-glutamic acid, purissimum ammonium nitrate, perchloric acid, sodium chloride, potassium chloride, ammonium persulfate and manganese chloride were from PANREAC (PRS) (Barcelona, Spain).

All other chemicals were of analytical grade.

\section{Protein measurement according to the method of Lowry}

The measurement of protein was carried out on a total volume of $200 \mu \mathrm{l}$ containing $50 \mu \mathrm{g}$ of bovine serum albumin and a variable amount of the chemical product, the influence of which is to be determined on the effectiveness of the method of Lowry. A volume of $2 \mathrm{ml}$ of the mixture (prepared with $100 \mu \mathrm{l}$ of $0.5 \%(\mathrm{w} / \mathrm{v})$ copper sulfate solution, $100 \mu \mathrm{l}$ of $1 \%(\mathrm{w} / \mathrm{v})$ potassium-sodium tartrate solution and $10 \mathrm{ml}$ of $2 \%$ (w/v) sodium carbonate solution) was added. The resulting mixture was shaken and incubated in the dark for $15 \mathrm{~min}$ at ambient temperature. Then, $200 \mu \mathrm{l}$ of Folin-Ciocalteus reagent (half diluted in $0.1 \mathrm{~N} \mathrm{NaOH}$ ) was added. The mixture was shaken once more and allowed to rest in the dark for $30 \mathrm{~min}$ to allow colour development. 
Absorbance of mixtures was measured at 660 $\mathrm{nm}$ with a spectrophotometer (GENESYS ${ }^{\mathrm{TM}} 5$ ) against a control containing no protein extract. These absorbances were further converted to percentage of variation of the amount of protein against the absorbance of mixture containing only $50 \mu \mathrm{g}$ of bovine serum albumin.

\section{RESULTS AND DISCUSSION}

\section{Influence of acids}

Among the tested acids, only ascorbic acid caused a very high overestimation of the amount of protein in the reaction mixture (Figure $1 b$ ). For an amount of $50 \mu \mathrm{g}$ of protein present in the reaction mixture, we obtained an estimation of $2000 \%$. This overestimation increased with the concentration of vitamin $\mathrm{C}$. The presence of double bonds in the structure of ascorbic acid may explain this result. These double bonds are similar to those present in aromatic amino acids such as phenylalanine, tyrosine, tryptophane and histidine. This high overestimation suggests that protein estimation in fruit juices, which are rich in vitamin $\mathrm{C}$ may not be reliable when the method of Lowry is used. Other quantitative methods for the assessment of the amount of protein based on peptide bonds such as that of Smith and Circles $^{6}$ and Bradford ${ }^{4}$ could be preferable.

Boric acid resulted in a slight overestimation of the amount of protein in the reaction mixture in a concentration dependent manner, while trichloroacetic acid and oxalic acid caused little or no variation in the amount of protein estimated irrespective of their concentration in the medium (Figure 1b).

Other acids such as metaphosphoric acid, hydrochloric acid, perchloric acid, propionic acid, sulfuric acid, acetic acid, saccharic acid, glutamic acid and molybdic acid resulted in an underestimation of the amount of protein in the reaction mixture (Figures $1 \mathrm{a}, 1 \mathrm{~b}$ and $1 \mathrm{c}$ ). This underestimation increased with the concentration of acids in the medium.

\section{Influence of organic solvents}

With organic solvents, propanol-1 and 2-methyl1-propanol induced an underestimation of the amount of protein in the medium, while isobutanol hardly exerted any influence on the amount of protein determined using Lowry method. Organic solvents resulting in an overestimation include ethanol, methanol, acetone and hexane (Figure 2). However, more accurate results were obtained when organic solvents used for protein extraction were evaporated before protein quantification with Lowry method.

\section{Influence of phenolic compounds}

All tested phenolic compounds exerted influence on the accuracy of protein estimation by the method of Lowry (figures $3 a$ and $3 b$ ). While only $p$-nitrophenol induced a slight underestimation of the amount of protein, the others: orcinol, 2-naphtol, naphto-resorcinol, resorcinol, phenol and 2,6-dichlorophenol caused a high overestimation of the protein level, reaching up to $3000 \%$ in some cases. This highest overestimation was obtained with naphto-resorcinol, followed by resorcinol, orcinol, phenol, 2-naphtol and 2,6dichlorophenol in that order (Figures $3 a$ and $3 b$ ). The overestimation of the amount of protein present in the phenolic compounds may be due to the presence of double bonds and probably to the number of $\mathrm{OH}$ grouping present in the structure of the molecule.

With monophenols, when the grouping of $\mathrm{NO}_{2}$ is grafted on the phenol, it loses its capability to interfere, but, when two atoms of chloride are present on the phenol, increased overestimation compared to that of phenol.

For polyphenols, the interference on protein estimation varied according to the number of $\mathrm{OH}$ groups present. Indeed, naphto-resorcinol containing three groups of $\mathrm{OH}$ in its structure showed the greatest interference, followed by resorcinol which has two $\mathrm{OH}$ groups. As for orcinol, it also possesses two $\mathrm{OH}$ groups but the presence of methyl group reduced the overestimation power of the molecule. 2-naphtol showed an overestimation power higher than that of phenol, probably because it possesses much more double bonds than phenol, since the two compounds possess only one $\mathrm{OH}$ group in their structure.

\section{Influence of salts}

Among all the tested salts (27 in all), only four induced an underestimation of the 
$1 \mathbf{a}$

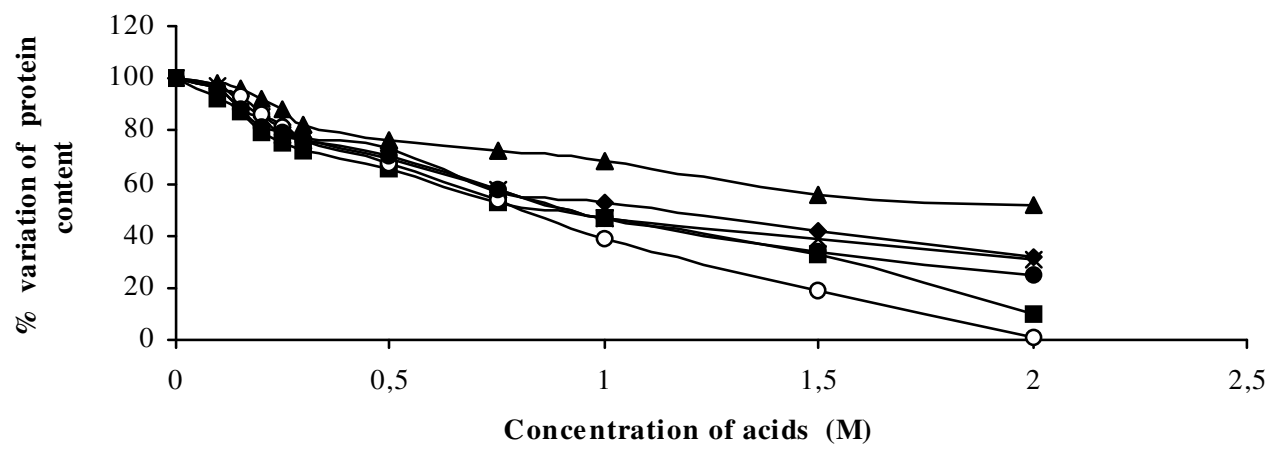

\begin{tabular}{lll}
$\longrightarrow$ Metaphosphoric acid & - Perchloric acid & $\longrightarrow$ Sulfuric acid \\
\hdashline Hydrochloric acid & $\multimap-$ Propionic acid & $\longrightarrow$ Acetic acid
\end{tabular}

1b

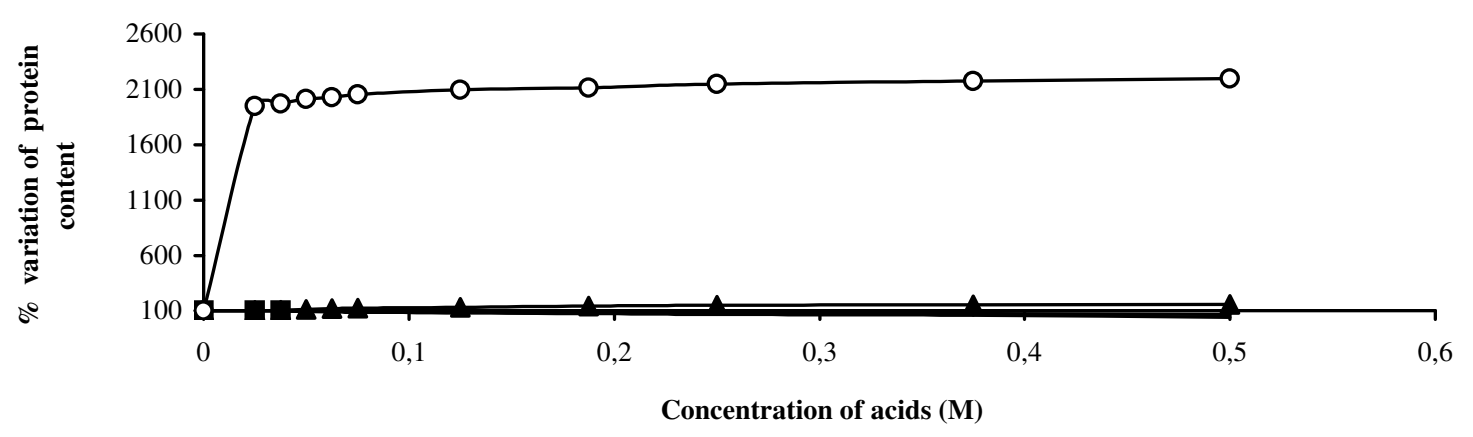

$\longrightarrow$ Trichloroacetic acid $\rightarrow$ Oxalic acid $\rightarrow$ Boric acid Ascorbic acid

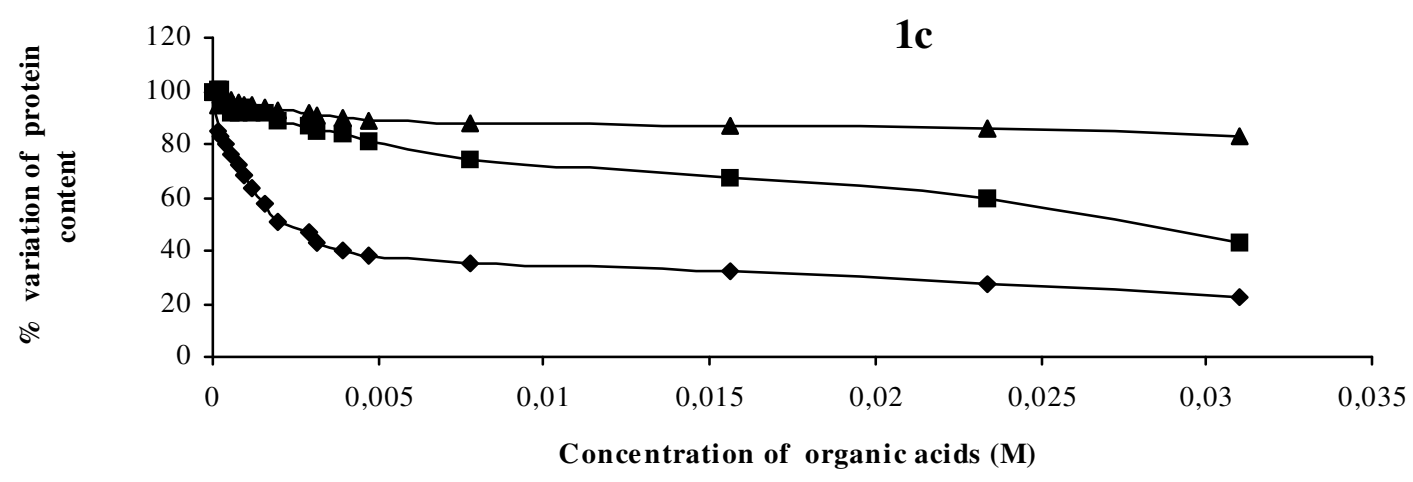

$\rightarrow$ Saccharic acid $\rightarrow$ Glutamic acid $\rightarrow$ Molybdic acid

Figure 1: Influence of acids on the efficiency of the method for protein content determination according to the technique of Lowry. 


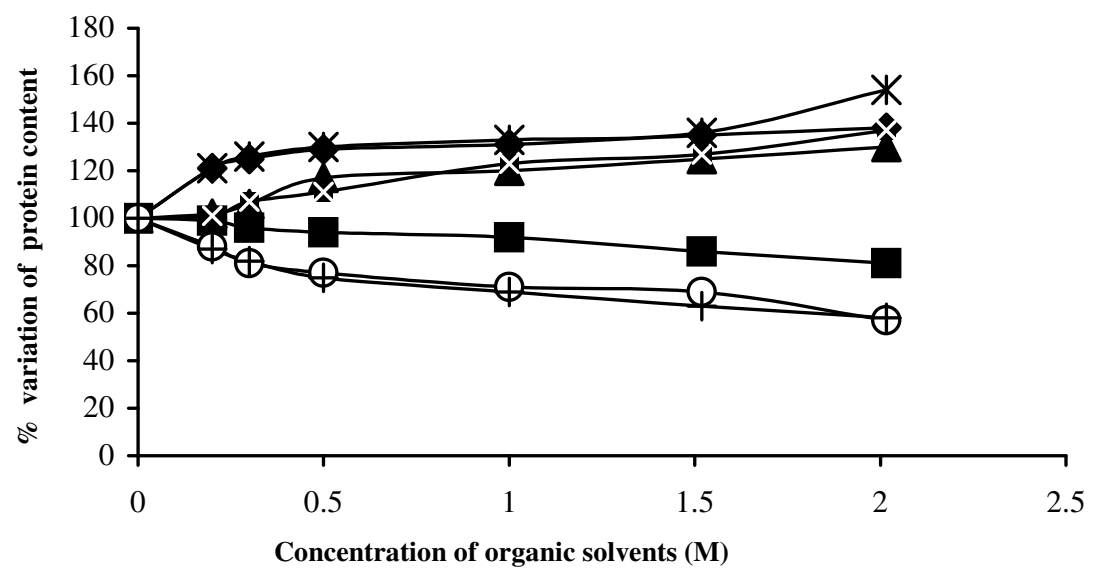

\begin{tabular}{|c|c|c|}
\hline$\multimap$ Hexane & - Isobutanol & - Methanol \\
\hline $\begin{array}{l}\rightarrow 区 \leftarrow \text { Acetone } \\
\longrightarrow \text { 2-methyl }\end{array}$ & $\rightarrow$ Ethanol & - - Propanol-1 \\
\hline
\end{tabular}

Figure 2: Influence of organic solvents on the efficiency of the method for protein content determination according to the technique of Lowry.

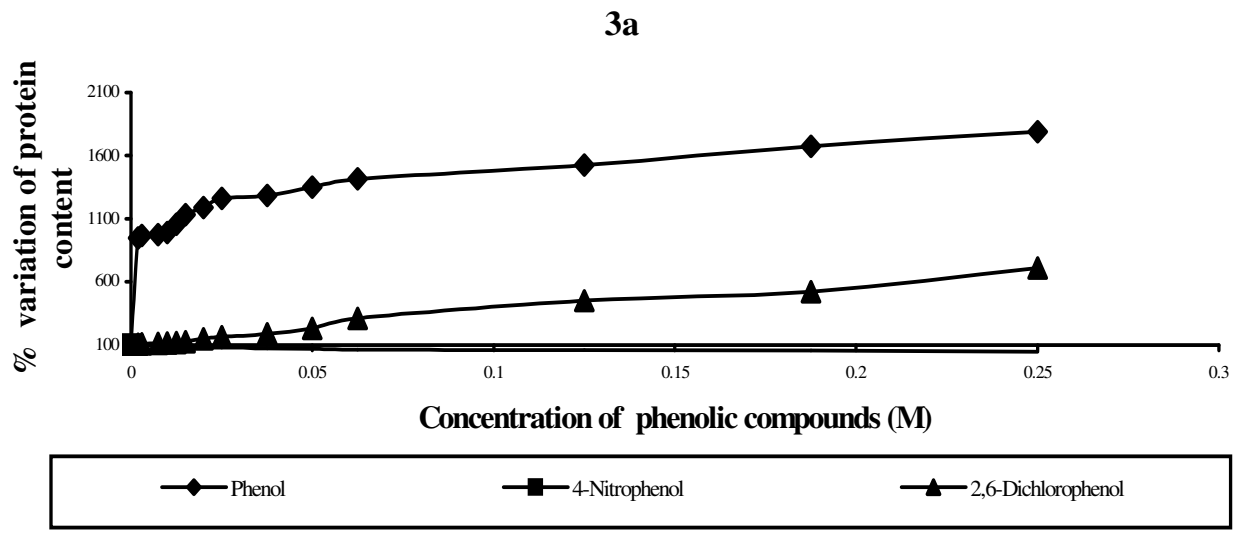

3b

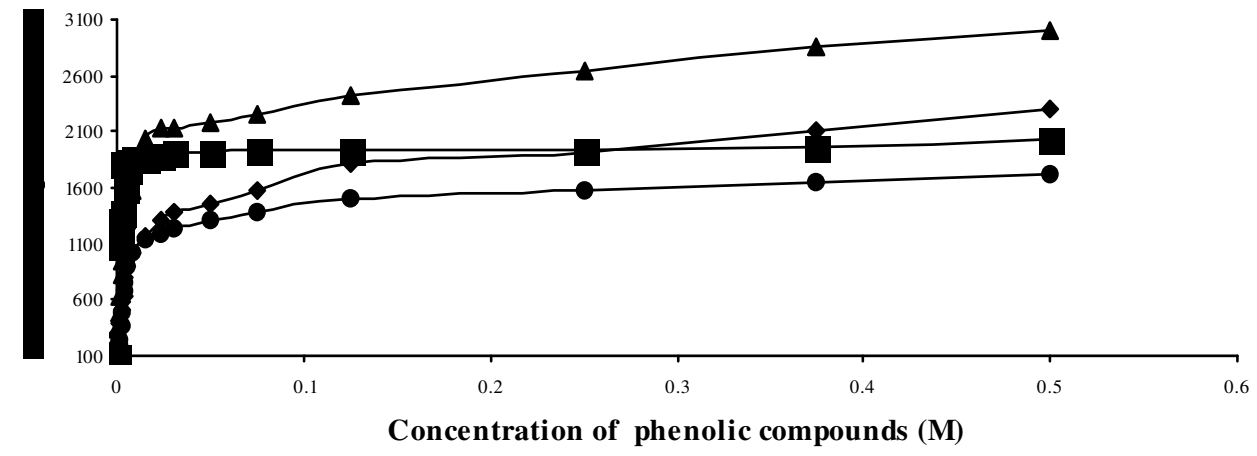

$\multimap$ Orcinol $\rightarrow$ 2-Naphtol $\rightarrow$ Naphtoresorcinol

- Resorcinol

Figure 3: Influence of phenolic compounds on the efficiency of the method for protein content determination according to the technique of Lowry. 
$4 a$

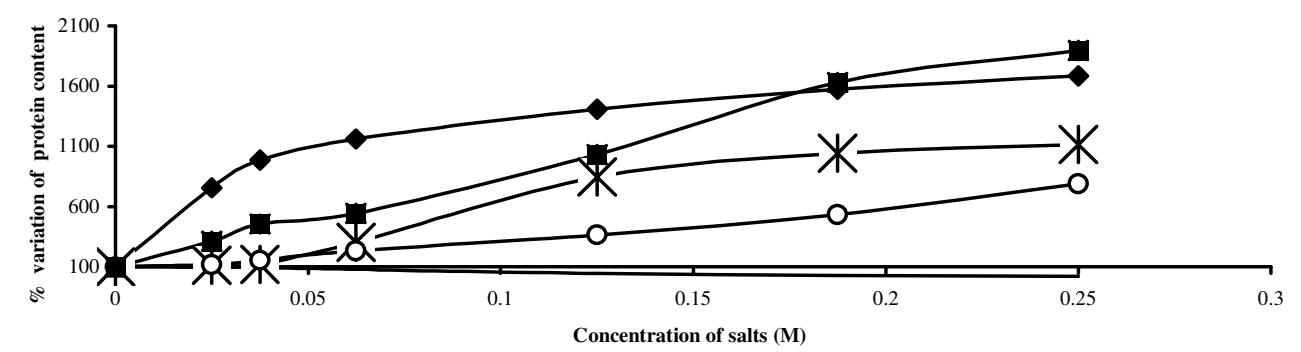

$\begin{array}{ll}\longrightarrow \text { Barium chloride } & -\boldsymbol{X} \text { - Potassium sulfate } \\ - \text { C Calcium hypochloride } & \rightarrow-\text { Copper acetate }\end{array}$

$4 b$

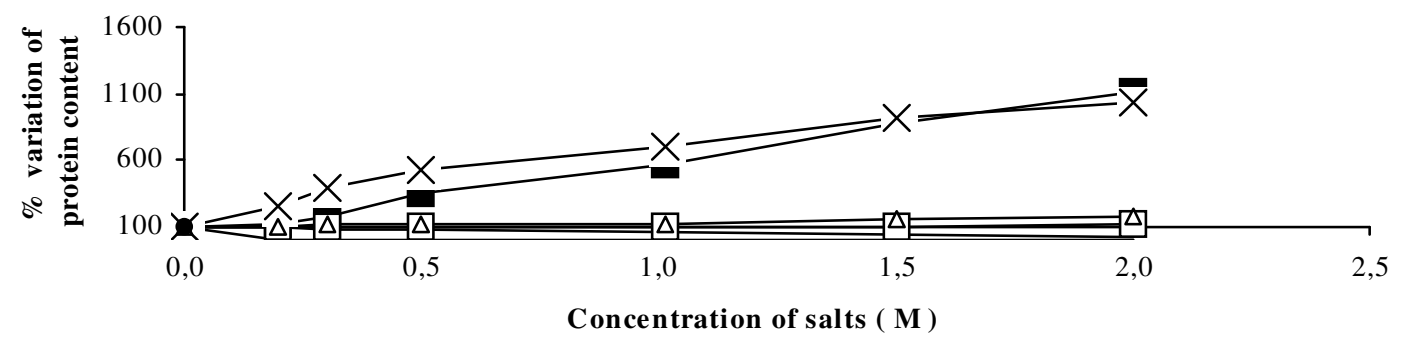

\begin{tabular}{|c|c|c|}
\hline - & $\rightarrow-$ Ammonium sulfate & $\neg-$ Sodium acetate \\
\hline$-\times-$ Potassium hydroxyde & $\triangle-$ Sodium thiosulfate & —- Sodium hypochloride \\
\hline
\end{tabular}

$4 c$

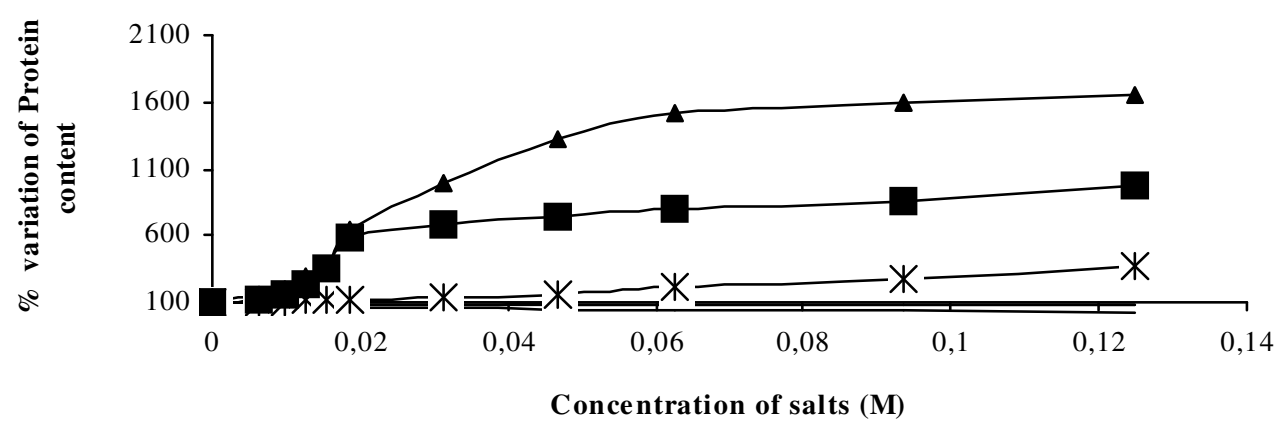
—-Ammonium persulfate
$\multimap-$ Ammonium oxalate
$\smile \longleftarrow$ Lead acetate
$\prec$ Disodium oxalate
- - Calcium chloride
$\rightarrow-$ Sodium sulfate 


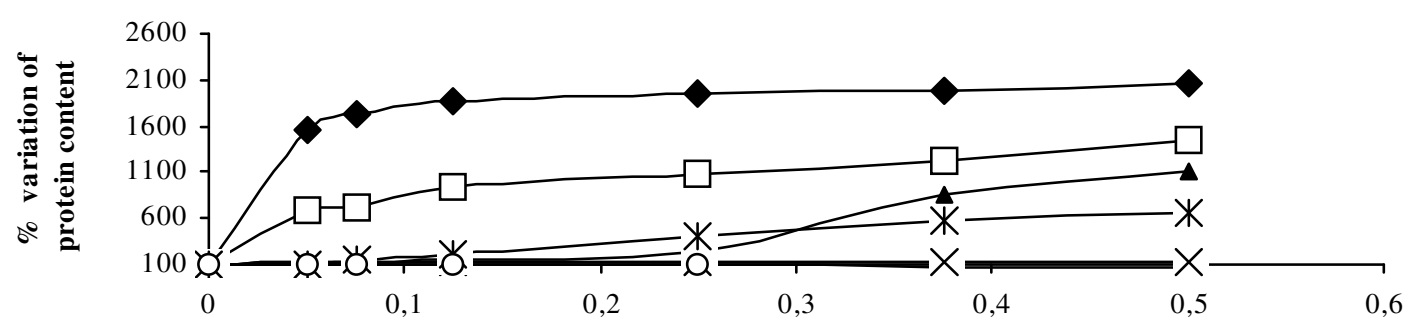

Concentration of mineral salts (M)

\begin{tabular}{ll|}
$\longrightarrow \longrightarrow$ Manganese chloride & - - Hydrogen phosphate \\
$\longrightarrow-$ Dihydrogen phosphate & $-\times-$ Hydrogen carbonate \\
$\longrightarrow \square$ Potassium hexacyanocarbonate (II) & $-*-$ Potassium chloride \\
$\longrightarrow-$ Ammonium nitrate & \\
\hline
\end{tabular}

$4 e$

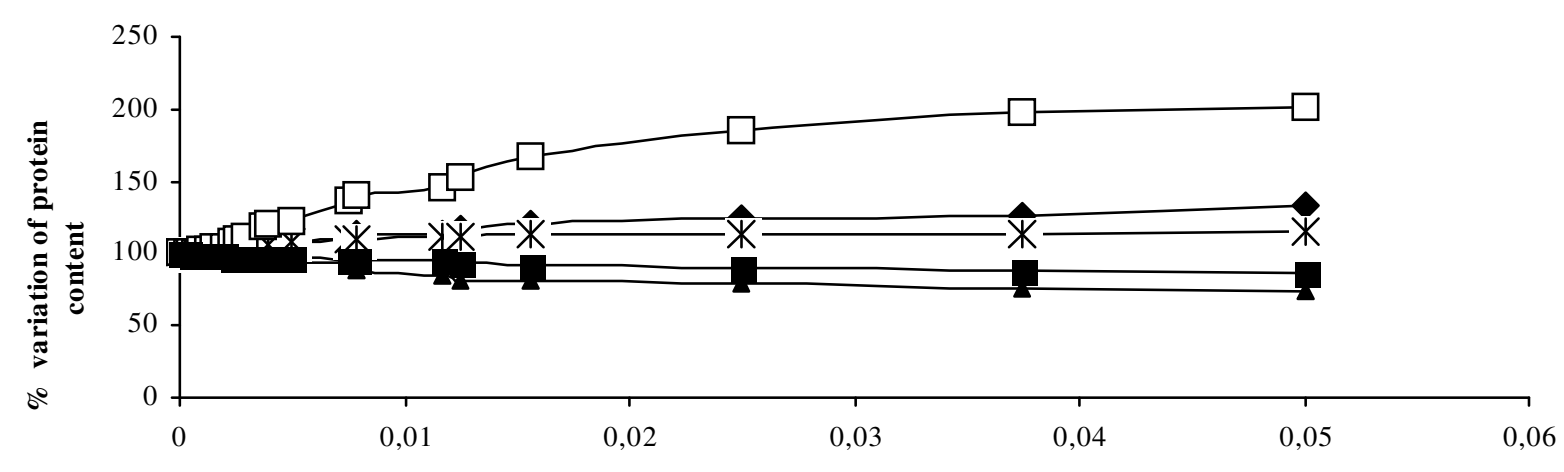

Concentation of salts ( M )

\begin{tabular}{|ll|}
$\longrightarrow \longrightarrow$ Bisublimed iodide & $-*-$ Potassium iodide \\
$\rightarrow \square$ Ammonium sulfate (III) & - - Ammonium vanadate \\
\hline
\end{tabular}

Figure 4: Influence of salts on the efficiency of the method for protein content determination according to the technique of Lowry.

amount of protein. These were sodium hypochlorite, ammonium molybdate, sodium chloride and ammonium persulfate (Figures 4a, $4 \mathrm{~b}, 4 \mathrm{c}, 4 \mathrm{~d}$ and $4 \mathrm{e})$. Six others hardly exerted any effect upon the effectiveness of the method of Lowry. These were sodium acetate, sodium hydrogen carbonate, ammonium nitrate, calcium carbonate, ammonium vanadate and disodic oxalate (Figures 4a, 4b, 4c, 4d and 4e). The salt that caused the greatest overestimation of protein include manganese chloride, potassium hexacyanoferate, lead acetate, sodium sulfate, potassium hydroxide, ammonium sulfate, barium chloride, copper acetate, potassium sulfate and calcium hypochlorite. Calcium seems to play an important role in the overestimation of the amount of protein, since sodium hypochlorite caused an underestimation whereas calcium hypochlorite resulted in an overestimation.

Ammonium sulfate which is the most widely used chemical in enzyme purification $^{7-10}$ 
processes induced an overestimation of the amount of protein. This has a lot of implications since this salt is used to precipitate enzymes ${ }^{11,12}$ and saturate chromatographic gels into salt ${ }^{13}$ when performing hydrophobic interaction chromatography. Its role in that process of fractionating is to make the medium more hydrophobic $^{14-18}$. In these two situations, the enzymatic solutions will contain this product which could produce false results when determining the amount of protein. This overestimation of protein will wrongly suggest a low specific activity for the enzyme, and thus a wrong conclusion that the enzyme in question is relatively non-stable. Hence, we suggest that for hydrophobic interaction chromatography, sodium thiosulfate can be used for the saturation process as it has little or no effect on Lowry method.

\section{Conclusion}

The influence of 57 chemicals (mineral and organic acids, organic solvents, phenolic compounds, mineral and organic salts) on the effectiveness of the method of Lowry for protein measurement was examined. The different chemical products were observed to have different effects on the efficiency of the method of Lowry. Some (ascorbic acid, boric acid, ethanol, methanol, acetone, hexane, oricinol, 2naphtol, resorcinol, naphto-resorcinol, phenol, 2,6-dichlorophenol, manganese chloride, potassium hexacyanoferate, lead acetate, sodium sulfate, potassium hydroxide, ammonium sulfate, barium chloride, copper acetate, potassium sulfate and calcium hypochlorite) brought about an overestimation while others (isobutanol, sodium acetate, sodium hydrogen carbonate, ammonium nitrate, calcium carbonate, ammonium vanadate and disodic oxalate) produced an underestimation yet others (metaphosphoric acid, hydrochloric acid, perchloric acid, propionic acid, sulfuric acid, acetic acid, saccharic acid, glutamic acid, molybdic acid, propanol-1, 2-methyl-1propanol, $p$-nitrophenol, sodium hypochlorite, ammonium molybdate, sodium chloride and ammonium persulfate) do not have any effect on the effeciency of the method of Lowry. Acidity of the medium, number $\mathrm{OH}$ groups and double bonds on the chemicals are found to play some roles in their capacity to influence protein estimation.

\section{ACKNOWLEGEMENT}

The authors are grateful to Professor Bernard Colas of University of Nantes (France), Unité de Recherche sur la Biocatalyse, CNRS-UMR 6204 , for technical assistance during this work.

\section{REFERENCES}

1. BIPEA

(1976)

Bureau interprofessionnel d'études analytiques. Recueil des méthodes d'analyse des communautés européennes. BIPEA, p.160, Grennevilles (France).

2. Gornall (1949), cited by Plummer, T.D. (1994) Introduction aux techniques de Biochimie. Ediscience Internationale, p.331, Paris (France).

3. Smith, P., Krohn, R. I., Hermanson, G. T., Mallia, A. K., Gartner, F. H., Provenzano, M. D., Fujimoto, E. K., Goeke, N. M., Olson, B. J. and Klenk D. C. (1985) Measurement of protein using bicinchoninic acid. Anal. Biochem. 150: 76-85.

4. Bradford, M. M. (1976) A rapid and sensitive method for the quantitation of microgram quantities of protein utilizing the principal of protein-dye bindingsnalyt. Biochem.12: 248-254.

5. Lowry, O. H., Rosebrough, N. J., Farr, A. L. and Randall, R. J. (1951) Protein measurement With the FolinPhenol reagent. J. Biol. Chem. 193: 265275.

6. Smith, A. and Circles J. (1978) Soybeans: Chemistry and Technology. AVI. Volume1: Proteins Publ., company, INC, westport, Connecticut.

7. Moyner, K. and Christiansen, G. (1984) Comparison of gel filtration and ammonium sulphate precipitation in the purification of diphtheria toxin and toxoid. Acta Pathol. Microbiol. Immunol. Scand. 92: 17-23.

8. Rudel, L. L., Lee, J. A., Morris, M. D. and Felts, J. M. (1974) Characterisation of plasma lipoproteins separated and purified by agarose column chromatography. Biochem. 139: 89-95. 
9. Abell, L. L., Levy, B. B., Brodie, B. B. and Kendall, F. E. (1952) A simplified method for estimation of cholesterol in serum. J. Biol. Chem. 195: 357-366.

10. Garcia-Parra, M, Mejiade, F., Gardia, M. and Weigandt, H. (1977) A new method for lipoprotein isolation by precipitation. In: Protides of Biological Fluids. Proceeding of $25^{\text {th }}$ colloquium Brugge. H. Peters (ed.), pp. 411-415. Pergamon Press, New York.

11. Nerurkar, S. V. and Taskar, S. P. (1985) Lipoprotein fractionation by precipitation: a comparison of two methods. J. Prostgrad. Med. 31: 89-94.

12. Onongbu, I. C. and Lewis, B. (1976) Lipoprotein fractionation method, simple quantitative procedure. Clin. Chem. Acta 71: 397-402.

13. Sine J. P. (2003) Séparation et analyse des biomolécules. Ellipses (ed.), pp. 720. Technosup, Paris.

14. Berggren, K., Egmond, M. R. and Tjerneld, F. (2000) Substitutions of surface amino acid residues of cutinase probed by aqueous two-phase partitioning. Biochem. Biophys. Acta 1481: 317-327.

15. Cowan, R. and Whittaker, R. G. (1990) Hydrophobicity indices for amino acid residues as determined by high performance liquid chromatography. Pepti. Res. 3: 75-80.

16. Lienqueo, M. E., Mahn, A. and Asenjo, J. A. (2002) Mathematical correlations for predicting protein retention times in hydrophobic interaction chromatography. $J$. Chromatogr. A 978: 71-79.

17. Miyazawa, S. and Jernizan, R. L. (1985) Most probable intermediates in protein folding-unfolding with a noninteracting globule-coil model. Macromolecules 18: 534-532.

18. Nicholls, A., Sharp, K. A. and Honig, B. (1991) Protein folding and association: insights from the interfacial and thermodynamic properties of hydrocarbons. Proteins: Struct. Funct. Gen. 11: 281-296. 